SHORT COMMUNICATION

\title{
The effects of seasonality on the foraging behavior of Tropidurus hispidus and Tropidurus semitaeniatus (Squamata: Tropiduridae) living in sympatry in the Caatinga of northeastern Brazil
}

\author{
Miguel F. Kolodiuk '; Leonardo B. Ribeiro ${ }^{1,2}$ \& Eliza M. X. Freire ${ }^{1}$
}

\begin{abstract}
In this study, we performed field observations of 38 and 84 specimens of the lizards Tropidurus hispidus (Spix, 1825) and Tropidurus semitaeniatus (Spix, 1825), respectively, inhabiting a Caatinga in the state of Rio Grande do Norte, northeastern Brazil, in order to describe the foraging behavior, measure the foraging intensity (number of movements, time spent stationary, distance traveled and number of attacks on preys) and investigate the effects of seasonality on the foraging strategies of these two species of lizards. During the dry season, both species showed no significant differences in foraging intensity. In the wet season, on the other hand, only the distance traveled was similar for both species. Tropidurus semitaeniatus displayed a larger mean number of movements $(9.8 \pm 1.2)$ and attacks on preys $(1.7 \pm 0.3)$ when compared to $T$. hispidus ( $3.0 \pm 0.8$ moves; $0.3 \pm 0.1$ attacks). Additionally, mean time spent stationary was significantly longer for T. hispidus ( $596.6 \pm 1.0$ seconds) than for T. semitaeniatus (587 \pm 2.1 seconds). Results suggest that the low number of movements and short distance traveled (maximum of $1000 \mathrm{~cm}$ during 10-minute intervals) are consistent with the categorization of $T$. hispidus and $T$. semitaeniatus as sit-and-wait foragers. Given our results, we conclude that both species co-exist under limiting conditions during the dry season, with similar foraging behavior and similar rates of foraging intensity, segregating with respect to these variables in the wet season.
\end{abstract}

KEY WORDS. Foraging mode; lizards; sympatric species.

Species of Tropidurus (Wied, 1820) are abundant diurnal lizards that occur from open formations to forested habitats (Frost 1992, Harvey \& Gutberlet 2000, Frost et al. 2001). In Brazil, the genus is widely distributed, with species living in the Amazon and the Atlantic forests (including "Restingas": coastal sand dunes habitats), the Caatingas and the Cerrados (ARAújo 1987, 1991, Rodrigues 1987, Rocha \& Bergallo 1990, VitT 1993, 1995, Vitt \& Caldwell 1993, Vitt et al. 1996, Ribeiro et al. 2008).

In South America, sympatry is common among co-generic species of lizards, and the genus Tropidurus is no exception (e.g. VitT 1991, 1995, Colli et al. 1992, Colli et al. 2002, FARIA \& ARAújo 2004, VAN Sluys et al. 2004). On rock outcrops within the Caatingas of northeastern Brazil, two species of Tropidurus occur sympatrically and syntopically: Tropidurus hispidus (Spix, 1825) and Tropidurus semitaeniatus (Spix, 1825). The former species is widely distributed, ranging from centraleastern and northeastern Brazil to Venezuela, whereas the latter is endemic to the Caatingas (VAnzolini et al. 1980).

Previous studies have investigated the diets of both $T$. hispidus and T. semitaeniatus in a Caatinga in the state of
Pernambuco (ViTt 1995), and the diet of T. hispidus populations in the Amazon Forest (VITT et al. 1996) and the rocky meadows ("campos rupestres") of the state of Minas Gerais (VAN SLuYs et al. 2004). Additionally, RibeIRo \& Freire (2009a) reported a hylid frog Scinax $x$-signatus previously unrecorded as prey for T. hispidus, in a Caatinga habitat in the state of Rio Grande do Norte. In contrast, information on the foraging behavior for the two Tropidurus species is scarce, particularly for the Caatingas. In fact, the only study mentioning the foraging behavior of T. hispidus was conducted in the Amazon region of Brazil (VITT et al. 1996). In addition, the role of T. semitaeniatus as a seed disperser (RibeIro et al. 2008) in the Caatinga (state of Rio Grande do Norte) and the drinking behavior of this species (Ribeiro \& Freire 2009b) were described.

In this study, we conducted seasonal and quantitative field observations on the foraging movements of $T$. hispidus and T. semitaeniatus in the Caatinga of northeastern Brazil. Because Tropidurus lizards are traditionally considered "sit-andwait" foragers (SCHOENER 1971, Rocha 1994), our initial prediction was that little variation would be observed between the 
foraging behaviors of these two species. We chose the Ecological Station of the Seridó (ESEC Seridó, Serra Negra do Norte, State of Rio Grande do Norte, $06^{\circ} 34^{\prime} \mathrm{S}, 37^{\circ} 15^{\prime} \mathrm{W}$ ) to conduct our field work. This region is part of the Morphoclimatic Domain of the Caatingas (sensu Aв'SÁBER 1974), more precisely the Northern Sertaneja Depression ecoregion, and contains two different areas with climatic extremes that give rise to lower vegetation characterizing the Seridó and the Cariri (Velloso et al. 2002). The climate is hot dry semi-arid (AB'SÁBER 1974), with a short irregular wet season between March and May, and rainfall varying from 500 and $700 \mathrm{~mm} /$ year. Mean annual temperatures range between $28^{\circ} \mathrm{C}$ and $30^{\circ} \mathrm{C}$ year-round, with maximum temperatures of more than $40^{\circ} \mathrm{C}$ and minimum temperatures between $17^{\circ} \mathrm{C}$ and $20^{\circ} \mathrm{C}$. Vegetation is hyperxerophillic shrubby-arboreal, with herbaceous undergrowth only in the wet season (VARELA-Freire 2002). The various rocky outcrops found within this vegetation are partly shady during the wet season, but become fully exposed to the sun during the dry season, as a result of deciduous seasonality.

We randomly selected five rocky outcrops surrounded by vegetation to observe the foraging behavior of $T$. hispidus and $T$. semitaeniatus. In order to account for seasonal differences, our observations took place both in the dry season, characterized by whitish vegetation, deciduous seasonality and increased sunlight exposure, and in the wet season, characterized by renewed foliage, reinvigorated vegetation and partial shade.

Foraging intensity is the measure of a predator's physiological and behavioral activity while searching for prey and while preying (Rосна et al. 2000). Since foraging intensity is expressed mainly in terms of movement, we have applied the following indices to assess the foraging intensity of T. hispidus and T. semitaeniatus: number of moves (NM), time spent stationary (TS in seconds), distance traveled (DT in cm; a measure inferred from the distance between the initial location of the lizard up to the furthest point traveled to), and number of attacks on preys (NAP). Observations took place twice a day (7$10 \mathrm{~h}$ and 14-17 h) over two consecutive days every month in the dry (October to December 2006) and wet (April to June 2007) (Nimer 1972) seasons. The time intervals above were selected based on our preliminary observations and published data (VITT 1995) indicating that they correspond to highest lizard activity. Samples were recorded using the Focal Animal method (Altmann 1974) for 10 minutes, alternating between observers whenever possible. All observations were carried out using a voice recorder and a digital regressive chronometer. In order to minimize observer's interference, we waited five minutes after the subject had been located to start recording. Whenever a lizard seemed to react to the presence of an observer, or when it disappeared from sight, the observation was disregarded, following VITT et al. (1996). The foraging indices (NM, TS, DT, NAP) were recorded and calculated for each lizard using the arithmetic mean by species and by seasonality. This methodology was adapted from that described in STRÜsSMAN et al. (1984), MAGNusson et al. (1985) and GaSNier et al. (1994). The Mann-Whitney U test (ZAR 1999) was used to determine whether T. hispidus and T. semitaeniatus exhibit different foraging behaviors, according to the indices applied, and to assess the existence of seasonal variations in foraging intensity between the species. Data were analyzed using SPSS version 13.0. The significance level adopted for obtaining critical values on the tests was 0.05 , and descriptive statistics are represented in the text as mean \pm 1 standard error.

A total of 122 focal samplings were conducted: 84 for $T$. semitaeniatus (43 in the dry season and 41 in the wet season,) and 38 for T. hispidus (22 in the dry season, and 16 in the wet season). Even though search and observation efforts were equivalent for both species, $T$. semitaeniatus was more abundant and was consequently encountered more often than T. hispidus. The analysis of foraging intensity, regardless of seasonality, showed that number of moves was significantly higher for T. semitaeniatus (11.2 \pm 0.9 moves; range 0-41 moves) than for T. hispidus (7.1 \pm 1.0 moves; range 0-28 moves; Mann-Whitney $\mathrm{U}$ test, $\mathrm{z}=-2,669$, $\mathrm{p}=0,008)$. Furthermore, time spent stationary was shorter for $T$. semitaeniatus ( $583.4 \pm 2.0$ seconds; range 497-600 seconds) than for T. hispidus (590.2 \pm 1.9 seconds; range 541-600 seconds; MannWhitney $\mathrm{U}$ test, $\mathrm{z}=-2.289, \mathrm{p}=0.022$ ). Lizards of both species traveled equivalent distances (T. semitaeniatus: $199.2 \pm 16.3 \mathrm{~cm}$; range 0-805 cm; T. hispidus: $206.9 \pm 34.5 \mathrm{~cm}$; range 0-1,000 cm; Mann-Whitney $\mathrm{U}$ test, $\mathrm{z}=-0.625, \mathrm{p}=0.532)$ and performed close numbers of attacks on preys (T. semitaeniatus: $1.5 \pm 0.2$ attacks; range 0-9 attacks; T. hispidus: $1.2 \pm 0.2$ attacks; range 0-8 attacks; Mann-Whitney U test, $\mathrm{z}=-1.050, \mathrm{p}=0.294$ ). Seasonal comparisons of foraging intensity between the two species showed no significant differences in the dry season (Tab. I). On the other hand, during the wet season only the distance traveled was similar for both species (Tab. I). Indices for both number of moves and number of attacks on preys were significantly higher for $T$. semitaeniatus, while time spent stationary was comparatively longer for T. hispidus (Tab. I).

During the dry season, the vegetation of the Caatinga becomes completely dry reducing the foraging sites of $T$. hispidus and T. semitaeniatus to rocky formations that serve as observation points (waiting sites) which are visited alternately during displacements. From these sites, the lizards wait with their heads pointing down, and quickly jump on to potential preys spotted moving through the leaf litter accumulated in the rock crevices or around the rocks. During the wet season, on the other hand, the vegetation of the Caatinga becomes invigorated and produces many flowers. The flowers attract insects such as bees, beetles and butterflies, acting as insect baits for the lizards that stay motionless near them. When an insect is spotted landing on a nearby flower, the lizard quickly jumps onto it. Furthermore, when foraging during the wet season, T. hispidus, a habitat generalist, benefits from including the flowers on the trees above the rocky surfaces for foraging. In contrast, T. semitaeniatus, 
typically saxicolous, does not climb to the highest parts of the trees and limits itself to capturing preys in the flowers of plants at the level of the rock surfaces (Figs 1 and 2).
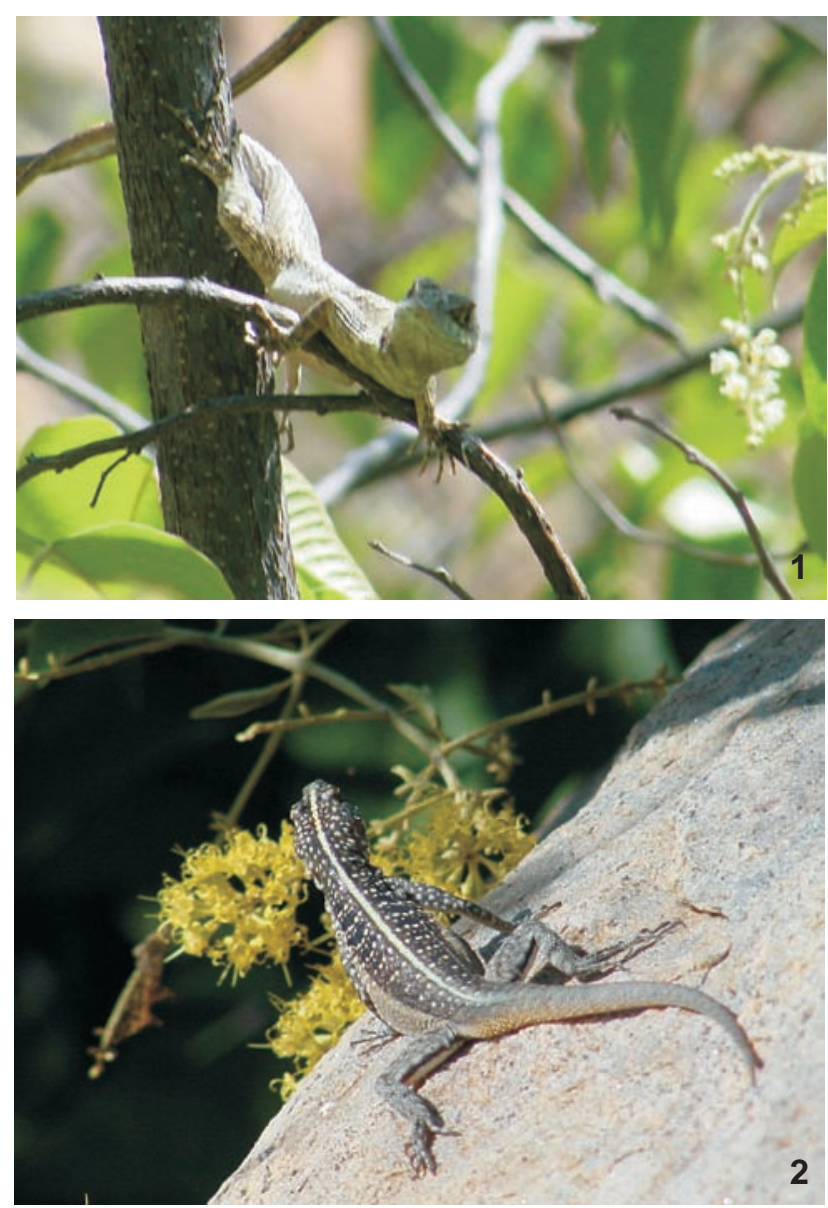

Figures 1-2. Tropidurus hispidus on tree branch (1) and T. semitaeniatus on the rocky outcrop (2), where both the lizards waiting for preys near an inflorescence, during the wet season at the Estação Ecológica do Seridó, Brazil.
Foraging mode has been considered of fundamental importance in interpreting ecological and behavioral characteristics of lizards, as well as the natural history of a species (HuEY et al. 1983, PiAnKa 1986, VitT 1990, VitT et al. 1996). Lizards are traditionally classified into two categories according to foraging mode: active foragers or sit-and-wait foragers (VITT \& CONGDON 1978, Huey \& Pianka 1981). Foraging in Tropidurus reflects a history of sit-and-wait foraging involving a set of associated characters in the family Tropiduridae and most of the Iguania (CoOPER 1994). The foraging behavior described here and the indices of foraging intensity, such as low number of movements and short distances traveled (HuEY \& PIANKA 1981) are consistent with the categorization of T. hispidus and T. semitaeniatus as sit-andwait foragers, similar all other tropidurids studied (e.g. HowlAND et al. 1990, Rocha \& Bergallo 1990, Vitt 1991, Colli et al. 1992, Vitt \& Carvalho 1995, VitT et al. 1996). Even though phylogeny is believed to play an important role in the foraging mode of lizards (CoOper 1995), the two foraging strategies mentioned above must be considered as extreme points of a variation gradient. Species can modulate their hunting strategies according to pressures imposed by the environment, such as seasonality (Huey \& Pianka 1981, Rocha 1994).

The foraging intensity indices for both number of moves and number of attacks on preys obtained for T. hispidus in the Caatinga are similar to those reported for the same species in the Amazon region (VITT et al. 1996), particularly during the wet season. On the other hand, our observations using the Focal Animal method, especially in the wet season, revealed differences in the foraging intensity of T. hispidus and T. semitaeniatus in regards to most indices evaluated (e.g. number of moves, time spent stationary, and number of attacks on preys), indicating that T. semitaeniatus is more active than T. hispidus (Tab. I). These differences support the idea that foraging intensity may vary between species even when they exhibit the same foraging strategy (GASNIER et al. 1994). Additionally, the number of moves and distance traveled for both $T$. hispidus and T. semitaeniatus were larger than those recorded for the polychrotid lizard Anolis auratus, also a sit-and-wait forager (MAGNUSSON et al. 1985), being smaller than those recorded for active foragers such as the teiid lizards Ameiva ameiva, Cnemidophorus lemniscatus and

Table I. Seasonal comparisons for measures of foraging intensity during ten-minute focal animal observations of $T$. hispidus (Th) and $T$. semitaeniatus (Ts) at the Ecological Station of the Seridó, Brazil. (NM) Number of moves, (TS) time spent stationary (seconds), (DT) distance traveled (cm), (NAP) number of attacks on preys. Data are represented as mean $\pm 1 \mathrm{SE}$ (range) and $p$ values are based on the Mann-Whitney $U$ test. Significant differences are highlighted with an asterisk.

\begin{tabular}{|c|c|c|c|c|c|c|}
\hline \multirow{2}{*}{ Index } & \multicolumn{3}{|c|}{ Dry season } & \multicolumn{3}{|c|}{ Wet season } \\
\hline & Th $(n=22)$ & Ts $(n=43)$ & $\mathrm{p}$ & Th $(n=16)$ & $\operatorname{Ts}(n=41)$ & $p$ \\
\hline NM & $10.1 \pm 1.4(3-28)$ & $12.5 \pm 1.4(0-41)$ & 0.374 & $3.0 \pm 0.8(0-11)$ & $9.8 \pm 1.2(1-38)$ & $0.0001^{*}$ \\
\hline TS & $585.5 \pm 2.9(541-598)$ & $580 \pm 3.4(497-600)$ & 0.528 & $596.6 \pm 1.0(585-600)$ & $587 \pm 2.1(549-599)$ & 0.0001 * \\
\hline DT & $252.5 \pm 48.1(10-1000)$ & $212.7 \pm 23.9(0-805)$ & 0.792 & $144.3 \pm 45.6(0-620)$ & $185.0 \pm 22.1(12-650)$ & 0.0820 \\
\hline NAP & $1.8 \pm 0.4(0-8)$ & $1.3 \pm 0.2(0-6)$ & 0.245 & $0.3 \pm 0.1(0-2)$ & $1.7 \pm 0.3(0-9)$ & $0.0030 *$ \\
\hline
\end{tabular}


Kentropyx calcarata. These differences fit the hypothesis that sitand-wait foraging and active foraging are extremes of a continuum of foraging strategies that has various intermediate degrees (Schoener 1971, Magnusson et al. 1985).

Our results show that the foraging behavior strategies of T. hispidus and T. semitaeniatus are affected by the marked seasonality of the Caatinga. During the harsher conditions imposed by the dry season (e.g. scarce food sources) the two species are constrained to coexist under limiting resources, a finding supported by the observed similarities in their foraging behavior and intensity. In the wet season, on the other hand, the different characteristics of the vegetation allow these two species to segregate from each other through different hunting strategies: whereas T. hispidus spends more time stationary near a single flower (or inflorescence), resulting in a lower number of attacks on preys, T. semitaeniatus moves more from flower to flower (or among inflorescences) performing a larger number of attacks. Finally, we conclude that the foraging behavior and intensity of T. hispidus and T. semitaeniatus living sympatrically on rocky outcrops in this area of the Caatinga has allowed their coexistence under limiting conditions in the dry season, acting as segregating factors that contribute to their coexistence in the wet season.

\section{ACKNOWLEDGEMENTS}

This study was carried out within the Programa de Pósgraduação em Psicobiologia of the Departamento de Fisiologia, Centro de Biociências, Universidade Federal do Rio Grande do Norte. We thank the Programa PELD/CNPq - Caatinga: Estrutura e Funcionamento for logistic support and two anonymous reviewers for invaluable criticism on the earlier version of the manuscript. L.B. Ribeiro and E.M.X. Freire received research grants from CNPq (141993/2006-5 and 304077/2008-9, respectively). The permission to conduct this study was granted by IBAMA (Permit 206/2006 and Process 02001.004294/03-15).

\section{LITERATURE CITED}

AB'SABER, A. 1974. O domínio morfoclimático semi-árido das caatingas brasileiras. Geomorfologia 43: 1-139.

Altmann, J. 1974. Observational study of behaviour: sampling methods. Behaviour 49: 227-267.

AraúJo, A.F.B. 1987. Comportamento alimentar dos lagartos: o caso dos Tropidurus do grupo Torquatus da Serra de Carajás, Pará (Sauria: Iguanidae). Encontro Anual de Etologia 5: 203-234.

Araújo, A.F.B. 1991. Structure of a white sand dune lizard community of coastal Brazil. Revista Brasileira de Biologia 51: 857-865.

Colli, G.R.; A.F.B. Araújo; R. Silveira \& F. Roma. 1992. Niche partitioning and morphology of two syntopic Tropidurus (Sauria: Tropiduridae) in Mato Grosso, Brazil.

Journal of Herpetology 26: 66-69.
Colli, G.R.; R.P. Bastos \& A.F.B. Araújo. 2002. The character and dynamics of the cerrado herpetofauna, p. 223-241. In: P.S. Oliveira \& R.J. MARQuis (Eds). The cerrados of Brazil: ecology and natural history of a neotropical savanna. New York, Columbia University Press, 424p.

Cooper JR, W.E. 1994. Prey chemical discrimination, foraging mode, and phylogeny, p. 95-116. In: L.J. VitT \& E.R. Pianka (Eds). Lizard ecology: historical and experimental perspectives. Princeton, Princeton University Press, 403p.

CoOper JR, W.E. 1995. Foraging mode, prey chemical discrimination, and phylogeny in lizards. Animal Behaviour 50: 973985.

FARIA, R.G. \& A.F.B. ARAúJo. 2004. Sintopy of two Tropidurus lizard species (Squamata: Tropiduridae) in a rocky cerrado habitat in central Brazil. Brazilian Journal of Biology 64: 775-786.

Frost, D.R. 1992. Phylogenetic analysis and taxonomy of the Tropidurus group of lizards (Iguania: Tropiduridae). American Museum Novitates 3033: 1-68.

Frost, D.R.; M.T. Rodrigues; T. Grant \& T.A. Titus. 2001, Phylogenetics of the lizard genus Tropidurus (Squamata: Tropiduridae: Tropidurinae): direct optimization, descriptive efficiency, and sensitivity analysis of congruence between molecular data and morphology. Molecular Phylogenetics and Evolution 21: 352-371.

Gasnier, T.R.; W.E. Magnusson \& A.P. Lima. 1994. Foraging activity and diet of four sympatric lizard species in a tropical rainforest. Journal of Herpetology 28: 187-192.

Harvey, M.B. \& R.L. Gutberlet. 2000. A phylogenetic analysis of the tropidurine lizards (Squamata: Tropiduridae), including new characters of squamation and epidermal microstructure. Zoological Journal of the Linnean Society 128: 189-233.

Howland, J.M.; L.J. VitT \& P.T. Lopez. 1990. Life on the edge: the ecology and life history of the tropidurine iguanid lizard Uranoscodon superciliosum. Canadian Journal of Zoology 68: 1366-1373.

Huey, R.B. \& E.R. Pianka. 1981. Ecological consequences of foraging mode. Ecology 62: 991-999.

Huey, R.B.; E.R. Pianka \& T.W. Schoener. 1983. Lizard ecology: studies of a model organism. Cambridge, Harvard University Press, 501p.

Magnusson, W.E.; L.J. Paiva; R.M. Rocha; C.R. Franke; L.A. KasPer \& A.P. Lima. 1985. The correlates of foraging mode in a community of Brazilian lizards. Herpetologica 41: 324-332.

Nimer, E. 1972. Climatologia da região Nordeste do Brasil. Introdução à climatologia dinâmica. Revista Brasileira de Geografia 34: 3-51.

PIANKA, E.R. 1986. Ecology and natural history of desert lizards. Princeton, Princeton University Press. 208p.

Ribeiro, L.B. \& E.M.X. Freire. 2009a. Tropidurus hispidus (NCN). Frog predation. Herpetological Review 40: 228-228.

Ribeiro, L.B. \& E.M.X. Freire. 2009b. Tropidurus semitaeniatus (NCN). Drinking behavior. Herpetological Review 40: 228229. 
Ribeiro, L.B.; M. Gogliath \& E.M.X. Freire. 2008. Tropidurus semitaeniatus (Squamata: Tropiduridae) as a seed disperser of the plant Commiphora leptophloeos (Burseraceae) in the caatinga of northeastern Brazil. Cuadernos de Herpetología 22: 91-94.

Ribeiro, L.B.; S.C. Gomides; A.O. Santos \& B.M. Sousa. 2008. Thermoregulatory behavior of the saxicolous lizard, Tropidurus torquatus (Squamata: Tropiduridae), in a rocky outcrop in Minas Gerais, Brazil. Herpetological Conservation and Biology 3: 63-70.

RochA, C.F.D. 1994. A ecologia de lagartos no Brasil: status e perspectivas, p. 35-57. In: L.B. NASCIMENTO; A.T. Bernardes \& G.A. CotтA (Eds). Herpetologia no Brasil I. Belo Horizonte, Fundação Biodiversitas e Fundação Ezequiel Dias, Universidade Católica de Minas Gerais, 134p.

Rocha, C.F.D. \& H.G. Bergallo. 1990. Thermal biology and flight distance of Tropidurus oreadicus (Sauria, Iguanidae) in an area of Amazonian Brazil. Ethology, Ecology and Evolution 2: 263-268.

Rocha, C.F.D.; D. Vrcibradic \& A.F.B. Araújo. 2000. Ecofisiologia de répteis de restingas brasileiras, p. 117-149. In: F.A. Esteves \& L.D. LACERDA (Eds). Ecologia de restingas e lagoas costeiras. Macaé, Núcleo de Pesquisas Ecológicas de Macaé e Universidade Federal do Rio de Janeiro, 394p.

Rodrigues, M.T. 1987. Sistemática, ecologia e zoogeografia dos Tropidurus do grupo torquatus ao sul do Rio Amazonas (Sauria, Iguanidae). Arquivos de Zoologia 31: 105-230.

Schoener, T.W. 1971. Theory of feeding strategies. Annual Review of Ecology and Systematics 2: 369-404.

Strüsmann, C.; M.B.R. Vale; M.H. Meneghini \& W.E. Magnusson. 1984. Diet and foraging mode of Bufo marinus and Leptodactylus ocellatus. Journal of Herpetology 18: 138-146.

Van Sluys, M.; C.F.D. Rocha; D. Vrcibradic; C.A.B. Galdino \& A.F. Fontes. 2004. Diet, activity and microhabitat use of two syntopic Tropidurus species (Lacertilia: Tropiduridae) in Mi- nas Gerais, Brazil. Journal of Herpetology 38: 606-611.

Vanzolini, P.E.; A.M.M. Ramos-Costa \& L.J. VitT. 1980. Répteis das Caatingas. Rio de Janeiro, Academia Brasileira de Ciências, 161p.

VArela-Freire, A.A. 2002. A caatinga hiperxerófila Seridó: a sua caracterização e estratégias para sua conservação. São Paulo, Academia de Ciências do Estado de São Paulo, 39p.

Velloso A.L.; E.V.S.B. Sampaio \& F.G.C. Pareyn. 2002. Ecorregiões: propostas para o bioma caatinga. Recife, Instituto de Conservação Ambiental, The Nature Conservancy do Brasil, 76p.

VITT, L.J. 1990. The influence of foraging mode and phylogeny on seasonality of tropical lizard reproduction. Papéis Avulsos de Zoologia 37: 107-123.

VITT, L.J. 1991. An introduction to the ecology of cerrado lizards. Journal of Herpetology 25: 79-90.

VITT, L.J. 1993. Ecology of isolated open-formation Tropidurus (Reptilia: Tropiduridae) in Amazonian lowland rain forest. Canadian Journal of Zoology 71: 2370-2390.

VITT, L.J. 1995. The ecology of tropical lizards in the caatinga of northeast Brazil. Occasional Papers of the Oklahoma Museum of Natural History 1: 1-29

VitT, L.J. \& C.M. CarvalHo. 1995. Niche partitioning in a tropical wet season: lizards in the lavrado area of northern Brazil. Copeia 1995: 305-329.

VITT, L. J. \& J.D. Congdon. 1978. Body shape, reproductive effort, and relative clutch mass in lizards: resolution of a paradox. American Naturalist 112: 595-608.

VitT, L.J. \& J.P. CALDWELl. 1993. Ecological observations on cerrado lizards in Rondônia, Brazil. Journal of Herpetology 27: 46-52.

VitT, L.J.; P.A. Zani \& J.P. Caldwell. 1996. Behavioural ecology of Tropidurus hispidus on isolated rock outcrops in Amazonia. Journal of Tropical Ecology 12: 81-101.

ZAR, J.H. 1999. Biostatistical analysis. Upper Saddle River, Prentice-Hall Inc., $4^{\text {th }}$ ed., 663p.

Submitted: 22.XI.2008; Accepted: 10.IX.2009.

Editorial responsibility: Kleber del Claro 